\title{
Australian National Training Packages - A Critical Analysis
}

\author{
Stanislaw Paul Maj ${ }^{1}$ \\ ${ }^{1}$ Engineering Institute of Technology, Australia \\ Correspondence: Stanislaw Paul Maj, Engineering Institute of Technology, 1031 Wellington St., West Perth, \\ 6005, Western Australia. Tel: 1300-138-522. E-mail: paulm@eit.edu.au \\ Received: May 27, 2016 \\ doi:10.5539/mas.v10n10p274 \\ Accepted: June 24, 2016 \\ Online Published: September 26, 2016 \\ URL: http://dx.doi.org/10.5539/mas.v10n10p274
}

\begin{abstract}
In the Australian Further Education sector all education is based on national training packages which are designed and managed to meet the needs of different industries. They provide specifications of training elements; the associate performance criteria; expected required knowledge and skills all benchmarked against defined evidence guides. Significantly the do not define content or how the content should be taught with regard to both depth and scope. The advantage of this approach is flexibility with respect to interpretation and implementation. The disadvantage is potential differences in implementation. Three implementations were evaluated to assess this potential problem. The results clearly show an extreme difference in implementation. This cannot be consistent with national benchmarked standards. Further work is needed.
\end{abstract}

Keywords: training, training packages, further and vocational education

\section{Introduction}

\subsection{Australian National Training Packages}

Within the Australian Further Education sector education is based on training packages. According to Service Skills Australia,

A training package is a set of nationally endorsed standards and qualifications for recognizing and assessing people's skills in a specific industry, industry sector or enterprise. (Australia)

Training packages are developed and managed nationally by the relevant Industry Skills Council (ISC) and consist of three components:

- Units of competency: define the skills and knowledge to operate effectively and how they need to be applied to perform effectively in a workplace context.

- Qualifications framework: groups of units of competency ranging from Certificate I to Graduate Diploma level.

- Assessment guidelines: the industry's preferred approach to assessment, including the qualifications required by assessors, the design of assessment processes and how assessments should be conducted. (Authority)

The ICAPMG501A Manage IT projects training package was evaluated according to a learning taxonomy and its implementation at different institutions in order to determine if this training package was equivalent regardless of institution.

\subsection{Anatomy of ICAPMG501A Manage IT projects Training Package}

Training packages are available nationally and can be obtained from a central web sited. All training packages are based on a standard template; only the headings directly relevant to this analysis are itemized below. According to training.gov:

Unit descriptor

This unit describes the performance outcomes, skills and knowledge required to manage information technology (IT) projects within a medium to large organization.

Application of the Unit

This unit applies to information and communications technology (ICT) practitioners who manage the initiation, implementation and completion of reasonably complex IT projects in terms of scope, risk, control and financial 
factors. The projects vary across a wide range of ICT, financial, management and business areas. The provision of specific IT-related project management within projects is a key component of the ICT environment.

Pre-requisites

Not applicable.

Employability Skills Information

This unit contains employability skills.

Elements and Performance criteria

Author comments - Elements describe the essential outcomes; performance criteria describe the performance needed to demonstrate the element has been achieved. The assessment of performance must be consistent with the evidence guide.

\begin{tabular}{|c|c|}
\hline Element & Performance Criteria \\
\hline $\begin{array}{l}\text { 1. } \begin{array}{l}\text { Manages project } \\
\text { definition activities }\end{array} \\
\text {. }\end{array}$ & $\begin{array}{l}\text { 1.1 Confirm organizational project governance policy and processes } \\
\text { 1.2 Confirm using problem or opportunity as well as project objectives } \\
\text { 1.3 Develop a project charter, including preliminary statement of project scope } \\
\text { and obtain sign-off } \\
\text { 1.4 Conduct a feasibility study and prepare a business case as necessary }\end{array}$ \\
\hline $\begin{array}{l}\text { 2. Undertake } \\
\text { planning }\end{array}$ & $\begin{array}{l}\text { 2.1 Plan information-gathering activities to determine project requirements, } \\
\text { constraints and risks } \\
\text { 2.2 Identify project partitioning on the basis of intended system development } \\
\text { life cycle and risk } \\
\text { 2.3 Prepare project work breakdown, schedule and budget } \\
\text { 2.4 Compile project-management plan documents as necessary to communicate } \\
\text { the intended management strategy for the project and obtain sign-off }\end{array}$ \\
\hline $\begin{array}{l}\text { 3. Establish the } \\
\text { project team }\end{array}$ & $\begin{array}{l}\text { 3.1 Identify and select team members, including roles and responsibilities, based } \\
\text { on project solution requirements } \\
\text { 3.2 Determine training and support needs of team members } \\
\text { 3.3 Establish project team values and agreed behavioral standards with team } \\
\text { members }\end{array}$ \\
\hline $\begin{array}{l}\text { 4. Manage project } \\
\text { execution activities }\end{array}$ & $\begin{array}{l}\text { 4.1 Monitor delivery and acceptance of assigned project team work activities and } \\
\text { manage individuals as necessary } \\
\text { 4.2 Monitor and control the quality of project deliverables } \\
\text { 4.3 Monitor and control project scope changes, risks and issues } \\
\text { 4.4 Manage system testing and hand-over activities }\end{array}$ \\
\hline $\begin{array}{l}\text { 5. Coordinate } \\
\text { closure }\end{array}$ & $\begin{array}{l}\text { 5.1 Prepare IT support plans and maintenance or support documents } \\
\text { 5.2 Obtain final project sign-off } \\
\text { 5.3 Conduct post-project review and document lessons learned } \\
\text { 5.4 Review and update disaster recovery plan } \\
\text { 5.5 Close project }\end{array}$ \\
\hline
\end{tabular}

Required Skills and Knowledge

This section describes the skills and knowledge required for this unit.

Required skills

- $\quad$ analytical skills to determine current system deficiencies and new system objectives

- communication skills to:

- gather stakeholder needs

- liaise with enterprise senior management

- counselling skills to mentor and coach team members and resolve conflict

- $\quad$ literacy skills to present options and recommendations in reports

- negotiation skills to ensure expected project outcomes are achievable

- numeracy and documentation skills to develop cost-benefit analyses 
- planning and organizational skills to plan project activities

- $\quad$ research skills to identify solution alternatives

- technical team management and leadership skills, including providing feedback.

Required knowledge

- characteristics of leaders and technical teams

- consultation and communication techniques and strategies

- how to establish technical teams and determine stages of team development

- estimation and cost-analysis techniques

- methods of communication and communication styles, including interviewing techniques

- objectives and benefits analysis

- $\quad$ organisational values, policies and processes

- performance management and project team appraisal methods

- processes for monitoring team and own performance

- $\quad$ project cash flow and budgeting

- range of project-management methods and tools

- $\quad$ self-awareness

- $\quad$ systems analysis and modelling techniques

- team roles and delegation within a multi-project methodology context

- technology solution models and frameworks.

Evidence Guide

The evidence guide provides advice on assessment and must be read in conjunction with the performance criteria, required skills and knowledge, range statement and the Assessment Guidelines for the Training Package.(Government)

\section{ICAPMG501A Manage IT Projects Training Package Analysis Method}

The five elements broadly define project management that could be applied in a wide range of industries. However the performance criteria do not define what should be taught to achieve these elements. This is in keeping with the function of training packages, which according to Service Skills Australia,

Despite the name, training packages do not describe how people should be trained. Rather they provide the nationally endorsed standards against which training can be develop and flexibly delivered to meet particular local, individual, industry and enterprise requirements. (Australia)

Consider element 2. Undertake project planning and two of the associated performance criteria (table 1). An elaboration of the performance criteria is defined in the training package section 'Required Skills and Knowledge' which identifies the essential skills and knowledge a person must be capable of in order to perform to an acceptable standard in the workplace - referred to as learning outcomes. In effect,

A learning outcome is a clear and specific statement of what students are expected to learn in a unit and to be able to demonstrate at its completion. (Wikipedia)

In the case of element number 2, the required knowledge learning outcomes are generic without any specific details. This is complemented by the Evidence guide section which provides advice on assessment (table 1).

Table 1. Element, Performance criteria, required knowledge, and Evidence guide

\begin{tabular}{|c|c|c|c|}
\hline Element & Performance criteria & Required knowledge & Evidence guide \\
\hline $\begin{array}{l}\text { 2. Undertake project } \\
\text { planning }\end{array}$ & $\begin{array}{l}\text { 2.2 Identify project } \\
\text { partitioning on the basis } \\
\text { of the intended system } \\
\text { development life cycle } \\
2.3 \text { Prepare project work }\end{array}$ & $\begin{array}{l}\text { Estimation and } \\
\text { cost-analysis } \\
\text { techniques } \\
\text { Project cash flow } \\
\text { and budgeting }\end{array}$ & $\begin{array}{l}\text { Define, plan, execute and } \\
\text { close a reasonably } \\
\text { complex project to meet } \\
\text { project requirements }\end{array}$ \\
\hline
\end{tabular}


breakdown, schedule and budget
- $\quad$ Range of project

management

methods and tools

- Systems analysis

and modelling

techniques

The standard to be achieved is further defined by the associated Australian Qualification Framework (AQF) and the expected outcomes (table 2) - which in this case is at Diploma level (Framework).

Table 2. AQF

\begin{tabular}{|c|c|c|c|}
\hline Summary & Knowledge & Skills & $\begin{array}{l}\text { Application of knowledge } \\
\text { and skills }\end{array}$ \\
\hline $\begin{array}{l}\text { Graduates at this level will } \\
\text { have specialized knowledge } \\
\text { and skills for } \\
\text { skilled/paraprofessional work } \\
\text { and/or further learning }\end{array}$ & $\begin{array}{l}\text { Graduates at this } \\
\text { level will have } \\
\text { technical and } \\
\text { theoretical } \\
\text { knowledge in a } \\
\text { specific area or a } \\
\text { broad field of work } \\
\text { and learning }\end{array}$ & $\begin{array}{l}\text { Graduates at this level } \\
\text { will have a broad range } \\
\text { of cognitive, technical } \\
\text { and communication } \\
\text { skills to select and apply } \\
\text { methods and } \\
\text { technologies to: } \\
\text { - analyse information } \\
\text { to complete a range } \\
\text { of activities } \\
\text { provide and transmit } \\
\text { solutions to } \\
\text { sometimes complex } \\
\text { problems } \\
\text { transmit information and } \\
\text { skills to others }\end{array}$ & $\begin{array}{l}\text { Graduates at this level will } \\
\text { apply knowledge and skills } \\
\text { to demonstrate autonomy, } \\
\text { judgment and defined } \\
\text { responsibility in known or } \\
\text { changing contexts and } \\
\text { within broad but } \\
\text { established parameters }\end{array}$ \\
\hline
\end{tabular}

The main advantage of this approach to teaching and learning is the ability to broadly interpret the guidelines and hence to be flexible for developing content to meet specific needs. However, because the required knowledge is generic and unspecified there is potentially considerable scope of radically different interpretations of both content and depth of treatment. For example the element 2, required knowledge Range of project management methods and tools is potentially subject to extremely diverse interpretations ranging from the rudimentary such a being able to list methods and tools to the other extreme of having an in-depth knowledge of them.

\subsection{Learning Taxonomy Evaluation of ICAPMG501A Manage IT Projects Training Package}

To produce lecture material and teach this subject a lecturer needs to know the expected depth to which the subject should be taught. The evidence guides along with the associated AQF level are indicators of the expected depth of treatment but do not provide sufficient guidance regarding depth of treatment.

The ICAPMG501A Manage IT projects training package was analyzed using the Structured Observation of Learning Outcomes (SOLO) taxonomy of assessing learning outcomes. The SOLO taxonomy defines four main taxonomy levels (excluding pre-structural) - uni-structural, multi-structural; relational and extended abstract. Uni-structural and multi-structural are low order learning outcomes allied to rote learning (table 3) (Biggs and Collis 1989). The relational and extended abstract categories represent deep, high order learning outcomes. The taxonomy levels can be related to terminology used in the training package being analyzed (Table 4). 
Table 3. SOLO Taxonomy

\begin{tabular}{|c|c|c|c|}
\hline Taxonomy level & $\begin{array}{l}\text { Level of } \\
\text { learning }\end{array}$ & Defined by: & Meaning \\
\hline $\begin{array}{l}\text { Extended } \\
\text { abstract }\end{array}$ & $\begin{array}{l}\text { High order } \\
\text { learning }\end{array}$ & $\begin{array}{l}\text { Generalize, } \\
\text { hypothesize }\end{array}$ & $\begin{array}{l}\text { Student conceptualizes at a level extending beyond } \\
\text { what has been dealt with in the actual teaching. } \\
\text { Understanding is transferrable and generisable to } \\
\text { different areas. }\end{array}$ \\
\hline Relational & $\begin{array}{l}\text { High order } \\
\text { learning }\end{array}$ & $\begin{array}{l}\text { Compare and contrast, } \\
\text { analyze, explain, } \\
\text { relate, apply }\end{array}$ & $\begin{array}{l}\text { Student understands multiple components and their } \\
\text { conceptual integration. }\end{array}$ \\
\hline Multi-structural & $\begin{array}{l}\text { Low order } \\
\text { learning }\end{array}$ & $\begin{array}{l}\text { Enumerate, list, } \\
\text { describe }\end{array}$ & $\begin{array}{l}\text { Student can understand several components but } \\
\text { understanding is discrete. The significance of the } \\
\text { whole is not understood with few if any relational } \\
\text { links }\end{array}$ \\
\hline Uni-structural & $\begin{array}{l}\text { Low order } \\
\text { learning }\end{array}$ & Identify, do & $\begin{array}{l}\text { Simple and obvious connections are made but broader } \\
\text { significance is not understood. }\end{array}$ \\
\hline
\end{tabular}

The performance criteria verbs in this training package are predominantly at the relational (high order learning) taxonomy level (table 4). This strongly implies the expectation of high order learning outcomes. This is in keeping with the evidence guide and the required ability to: define, plan, execute and close a reasonably complex project to meet project requirements.

Table 4. Evaluation of performance criteria

\begin{tabular}{lll}
\hline Taxonomy level & & Elements and performance criteria \\
\hline Extended abstract & High order learning & \\
Relational & High order learning & Develop, plan, establish, conduct, prepare, compile, manage \\
Multi-structural & Low order learning & Monitor, determine \\
Uni-structural & Low order learning & Confirm, identify \\
\hline
\end{tabular}

\section{Results}

To be compliant with regulatory standards each institution is required to generate further documents that include:

- Training and Assessment Strategy (TAS)

- Learning Plan

- Lesson Plans or lecture materials

- Assessment Information

- Assessment guides

- Assessment matrix

Three implementations were evaluated. Points to note are:

- $\quad$ Only the resources provided were analyzed; no classroom observations were made

- The resources provided were all deemed to be sufficient for any lecturer to teach the subject

- All implementations were compliant with regard to national regulatory standards

- Student contact time for implementation 1 and 2 was one day per week; for implementation 3 contact time was one hour per week. However there was an expectation of significant student self-study time

- All implementations tracked the normal project management sequence with allied topics

- All implementations had received positive student feedback

The lecture material and all available supporting materials of both implementations were evaluated according to the SOLO taxonomy levels. 
Table 5. Implementation 1

\begin{tabular}{|c|c|c|}
\hline Implementation 1 & Analysis & Supporting documents \\
\hline $\begin{array}{ll}\text { 1. } & \text { Project } \\
\text { Framework }\end{array}$ & $\begin{array}{l}43 \text { slides } \\
\text { Predominantly definitions; no in depth } \\
\text { treatment found } \\
\text { Minimal elaboration }\end{array}$ & $\begin{array}{l}\text { Sample PM methodologies } \\
\text { Worksheet } \quad(2 \quad \text { pages } \\
\text { superficial })\end{array}$ \\
\hline 2. Scope & $\begin{array}{l}8 \text { slides } \\
\text { Predominantly definitions; no in depth } \\
\text { treatment found } \\
\text { Minimal elaboration }\end{array}$ & \\
\hline 3. Business model & $\begin{array}{l}7 \text { slides with diagrams only and no supporting } \\
\text { text }\end{array}$ & \\
\hline 4. Stakeholders & Unknown & \\
\hline $\begin{array}{ll}5 . & \text { Work Breakdown } \\
& \text { Structure (WBS) } \\
\end{array}$ & $\begin{array}{l}\text { slides } \\
\text { Minimal elaboration }\end{array}$ & $\begin{array}{l}\text { Worksheet ( } 2 \text { pages) } \\
\text { Microsoft project case study }\end{array}$ \\
\hline 6. Budget & $\begin{array}{l}5 \text { slides } \\
\text { Predominantly definitions; no in depth } \\
\text { treatment found } \\
\text { Minimal elaboration }\end{array}$ & Worksheet (2 pages) \\
\hline 7. $\quad$ Risk & $\begin{array}{l}41 \text { slides } \\
\text { Definitions; some elaborations }\end{array}$ & \begin{tabular}{lr} 
Risk & \multicolumn{2}{c}{ Management } \\
documentation for to \\
professional bodies
\end{tabular} \\
\hline 8. Quality control & $\begin{array}{l}23 \text { slides } \\
\text { Generic discussion, some class activities }\end{array}$ & Two handouts \\
\hline 9. Communication & $\begin{array}{l}12 \text { slides } \\
\text { No in depth treatment found } \\
\text { Minimal elaboration }\end{array}$ & 6 diagrams - unknown use \\
\hline $\begin{array}{l}\text { 10. Change } \\
\text { management }\end{array}$ & $\begin{array}{l}5 \text { slides } \\
\text { No in depth treatment found } \\
\text { Minimal elaboration }\end{array}$ & Sample change request form \\
\hline 11. Human resources & $\begin{array}{l}20 \text { slides } \\
\text { Predominantly definitions; no in depth } \\
\text { treatment found } \\
\text { Minimal elaboration }\end{array}$ & \\
\hline 12. Human resources & Duplication of above & \\
\hline 13. Scheduling & 14 slides & $\begin{array}{l}\text { Communication styles } \\
\text { Worksheet ( } 4 \text { pages }) \\
\text { Article ( } 9 \text { pages })\end{array}$ \\
\hline $\begin{array}{r}\text { 14. Business } \\
\text { solutions }\end{array}$ & 5 slides & \\
\hline 15. & Total author generated material: 190 slides & \\
\hline Supporting material & $\begin{array}{l}\text { Textbook provided slides }- \text { good topics } \\
\text { coverage. } 41 \text { slides supplied by publisher }\end{array}$ & \\
\hline Supporting material & Case study material & \\
\hline
\end{tabular}

Points to note include:

- $40 \%$ of all lectures consist of less than 10 slides

- $60 \%$ of lectures consist of 20 slides or less

- Average of 13 slides per 8 hours of tuition

- Topics not included:

1. Systems, system boundary

2. Hierarchical top down decomposition, sequencing, concurrency 
3. Tutorials on using Microsoft Project

4. System development life cycle, RFP, proposal

5. Contract law

6. Contract types (e.g. firm fixed price etc.)

7. Specification methods

8. Quality Function Deployment (or similar)

9. Direct and Indirect costs

10. Estimation methods (e.g. analogy, parametric etc.)

11. Well defined work packages

Table 6. Implementation 2

\begin{tabular}{|c|c|c|}
\hline Implementation 2 & Analysis & Supporting documents \\
\hline 1. Project management & $\begin{array}{l}52 \text { slides } \\
\text { Overview }\end{array}$ & PMBOK reference \\
\hline 2. Systems & $\begin{array}{l}51 \text { slides } \\
\text { Comprehensive, in-depth treatment of topic }\end{array}$ & Microsoft project \\
\hline $\begin{array}{ll}\text { 3. } & \text { Systems Development } \\
& \text { Life Cycle (SDLC) } \\
\end{array}$ & $\begin{array}{l}81 \text { slides } \\
\text { Comprehensive, in-depth treatment of topic }\end{array}$ & \\
\hline 4. Contract law & $\begin{array}{l}74 \text { slides } \\
\text { Comprehensive, in-depth treatment of topic }\end{array}$ & Extensive student exercises \\
\hline 5. Budget & $\begin{array}{l}67 \text { slides } \\
\text { Comprehensive, in-depth treatment of topic }\end{array}$ & Extensive student exercises \\
\hline 6. Specification & $\begin{array}{l}66 \text { slides } \\
\text { Comprehensive, in-depth treatment of topic }\end{array}$ & Extensive student exercises \\
\hline $\begin{array}{ll}\text { 7. } & \text { Quality Function } \\
& \text { Deployment (QFD) }\end{array}$ & $\begin{array}{l}64 \text { slides } \\
\text { Comprehensive, in-depth treatment of topic }\end{array}$ & Extensive student exercises \\
\hline $\begin{array}{l}\text { 8. Work Breakdown } \\
\text { Structure (WBS) }\end{array}$ & $\begin{array}{l}132 \text { slides } \\
\text { Comprehensive, in-depth treatment of topic }\end{array}$ & $\begin{array}{l}\text { Detailed case studies } \\
\text { implemented in Microsoft } \\
\text { Project }\end{array}$ \\
\hline 9. $\quad$ Scheduling & $\begin{array}{l}70 \text { slides } \\
\text { Comprehensive, in-depth treatment of topic }\end{array}$ & \\
\hline 10. PERT & $\begin{array}{l}63 \text { slides } \\
\text { Comprehensive, in-depth treatment of topic }\end{array}$ & Extensive student exercises \\
\hline 11. Risk & $\begin{array}{l}83 \text { slides } \\
\text { Comprehensive, in-depth treatment of topic }\end{array}$ & $\begin{array}{l}\text { Exemplar template } \\
\text { Extensive student exercises }\end{array}$ \\
\hline & Total author generated material: 803 slides & \\
\hline $\begin{array}{l}\text { Recorded tutorial on } \\
\text { supporting material }\end{array}$ & 22 slides & \\
\hline $\begin{array}{l}\text { Recorded tutorial on } \\
\text { supporting material }\end{array}$ & 89 slides & \\
\hline $\begin{array}{l}\text { Recorded tutorial on } \\
\text { supporting material }\end{array}$ & 53 slides & \\
\hline $\begin{array}{l}\text { Recorded tutorial on } \\
\text { supporting material }\end{array}$ & 48 slides & \\
\hline $\begin{array}{l}\text { Recorded tutorial on } \\
\text { supporting material }\end{array}$ & 140 slides & \\
\hline
\end{tabular}

Points to note include:

- Average of 73 slides per 8 hours of tuition

- Four additional recorded tutorials on supporting material 
- $\quad$ Each lecture included extensive interactive exercises

- Comprehensive subject coverage with respect to both scope and depth

Table 7. Implementation 3

\begin{tabular}{|c|c|c|}
\hline Implementation 3 & Analysis & Supporting documents \\
\hline 1. Introduction & $\begin{array}{l}17 \text { slides } \\
\text { Overview }\end{array}$ & $\begin{array}{l}\text { Lecture material on } \\
\text { systems engineering }-24 \\
\text { slides }\end{array}$ \\
\hline $\begin{array}{ll}\text { 2. } & \text { System } \\
\text { Development Life } \\
\text { Cycle }\end{array}$ & $\begin{array}{l}79 \text { slides } \\
\text { Comprehensive, in-depth treatment of topic }\end{array}$ & Contracts -40 slides \\
\hline 3. Project and systems & $\begin{array}{l}42 \text { slides } \\
\text { Comprehensive, in-depth treatment of topic }\end{array}$ & $\begin{array}{l}\text { Waterfall and Agile - } 11 \\
\text { slides } \\
\text { QFD - } 10 \text { slides }\end{array}$ \\
\hline 4. Planning & $\begin{array}{l}60 \text { slides } \\
\text { Comprehensive, in-depth treatment of topic }\end{array}$ & Line of balance 23 slides \\
\hline 5. Scheduling & $\begin{array}{l}54 \text { slides } \\
\text { Comprehensive, in-depth treatment of topic }\end{array}$ & $\begin{array}{l}\text { Resource levelling - } 18 \\
\text { slides }\end{array}$ \\
\hline $\begin{array}{l}\text { 6. Critical Path } \\
\text { Method }\end{array}$ & $\begin{array}{l}28 \text { slides } \\
\text { Comprehensive, in-depth treatment of topic }\end{array}$ & Comprehensive 75 slides \\
\hline 7. PERT & $\begin{array}{l}13 \text { slides } \\
\text { Overview only }\end{array}$ & $\begin{array}{l}\text { Comprehensive } \\
52 \text { slides } \\
\text { Resource allocation } 21 \\
\text { slides } \\
\text { Critical chain } 80 \text { slides }\end{array}$ \\
\hline $\begin{array}{l}\text { 8. Cost Estimating } \\
\text { and Budgeting }\end{array}$ & $\begin{array}{l}38 \text { slides } \\
\text { Basics plus some subject elaboration }\end{array}$ & \\
\hline $\begin{array}{l}\text { 9. Project Quality } \\
\text { Management }\end{array}$ & $\begin{array}{l}54 \text { slides } \\
\text { Comprehensive, in-depth treatment of topic }\end{array}$ & \\
\hline $\begin{array}{l}\text { 10. Project Risk } \\
\text { Management }\end{array}$ & $\begin{array}{l}43 \text { slides } \\
\text { Comprehensive, in-depth treatment of topic }\end{array}$ & \\
\hline $\begin{array}{l}\text { 11. Project tracking-- } \\
\text { execution and } \\
\text { control }\end{array}$ & $\begin{array}{l}67 \text { slides } \\
\text { Comprehensive, in-depth treatment of topic }\end{array}$ & \\
\hline \multirow[t]{2}{*}{$\begin{array}{l}\text { 12. } \text { Project - } \\
\text { evaluation, } \\
\text { implementation and } \\
\text { closure }\end{array}$} & $\begin{array}{l}28 \text { slides } \\
\text { Overview }\end{array}$ & \\
\hline & Total slides: 523 & $\begin{array}{l}\text { Total supplementary } \\
\text { slides: } 354\end{array}$ \\
\hline
\end{tabular}

Points to note include:

- Average of 33 slides lecture

- Ten topics available as supplementary material providing further scope and depth

- Comprehensive subject coverage with respect to both scope and depth

\section{Discussion}

Three implementations of the training package ICAPMG501A Manage IT projects were evaluated. It should be stressed that this analysis should not be seen as a criticism of any of the implementations as all implementations were fully moderated and validated - hence deemed to be compliant to a national standard. As such they all met the training package requirements regarding elements, their performance criteria and required skills and knowledge based on the evidence guide. All three implementations had received positive student feedback. In addition to which they were all fully compliant with regard to the associated documentation. 
- Training and Assessment Strategy (TAS)

- Learning Plan

- Lesson Plans or lecture materials

- Assessment Information

- Assessment guides

- Assessment matrix

Whilst the number of slides may seem a crude evaluation metric, it proved to be strongly indicative of both the scope and depth of treatment (table 8). Implementation 1 had numerous instances of extremely limited number of lecture slides. With this seeming paucity of material there was no evidence of:

- Scaffolding (progressing from simple to complex i.e. from uni-structural to multi-structural to relational);

- Worked examples by demonstration and associated student exercises

However it is acknowledged that during student contact time there may well have been lecturer led discussions based on the case study provided. However the supporting lecture material did not appear to support high order learning of the principles and practices of project management sufficient to conduct an in-depth case study.

Table 8. Summary

\begin{tabular}{lllll}
\hline & $\begin{array}{l}\text { Total } \\
\text { number of } \\
\text { slides }\end{array}$ & $\begin{array}{l}\text { Supporting } \\
\text { material - total } \\
\text { number of slides }\end{array}$ & Scope and depth of treatment & SOLO taxonomy level \\
\hline $\begin{array}{l}\text { Implementation } \\
1\end{array}$ & 190 & 41 & $\begin{array}{l}\text { Significant number of topics } \\
\text { not taught }\end{array}$ & $\begin{array}{l}\text { Predominately low order } \\
\text { learning }\end{array}$ \\
\hline $\begin{array}{l}\text { Implementation } \\
2\end{array}$ & 803 & 352 & $\begin{array}{l}\text { Comprehensive }- \text { all major } \\
\text { topics addressed }\end{array}$ & $\begin{array}{l}\text { Consistent with } \\
\text { relational knowledge, } \\
\text { high order learning }\end{array}$ \\
\hline $\begin{array}{l}\text { Implementation } \\
3\end{array}$ & 523 & 354 & $\begin{array}{l}\text { Comprehensive - consistent } \\
\text { with relational knowledge, } \\
\text { high order learning }\end{array}$ & $\begin{array}{l}\text { Consistent with } \\
\text { relational knowledge, } \\
\text { high order learning }\end{array}$ \\
\hline
\end{tabular}

Despite the extremely wide variation in both scope and depth all three implementations are considered to be equivalent nationally. This paper concludes that this cannot be supported from not only content but also a pedagogical perspective. Further, more comprehensive evaluations are needed.

\section{References}

Australia, S. S. (2015). What is a training package? Rterieved from https:/www.serviceskills.com.au/ about-training-packages

Authority, I. S. Q. (2015). Rterieved from http://www.asqa.gov.au/about/australias-vet-sector/ training-packages $1 . \mathrm{html}$

Biggs, J., \& Collis, K. (1989). Towards a Model of School-based Curriculum Development and Assessment Using the SOLO Taxonomy. Australian Journal of Education, 33(2), 151-163.

Framework, A. Q. (2016). AQF levels.

Government, A. (2016). What is a training package? Rterieved from http://training.gov.au/Training/Details/ ICAPMG501A

Wikipedia. (2016). Training Packages (Australia).

\section{Copyrights}

Copyright for this article is retained by the author(s), with first publication rights granted to the journal.

This is an open-access article distributed under the terms and conditions of the Creative Commons Attribution license (http://creativecommons.org/licenses/by/4.0/). 